\title{
Study on the Properties of Immobilized Biocatalysts with Lipase Activity Produced by Yarrowia lipolytica in Batch Culture
}

\author{
I. A. Stolarzewicz, ${ }^{\text {a }}$ P. Zaborniak, ${ }^{\text {b }}$ \\ A. U. Fabiszewska, a," and E. Białecka-Florjańczyk ${ }^{a}$ \\ ${ }^{a}$ Department of Chemistry, Faculty of Food Sciences, Warsaw University \\ of Life Sciences, Nowoursynowska Street 159, 02-787, Warsaw, Poland \\ ${ }^{b}$ Interfaculty Department of Biotechnology, Warsaw University of Life \\ Sciences, Nowoursynowska Street 159, 02-787, Warsaw, Poland
}

doi: 10.15255/CABEQ.2016.833

Original scientific paper Received: February 9, 2016

Accepted: July 13, 2017

\begin{abstract}
Three kinds of matrices (calcium alginate, gelatin, and PVA) were employed as supports to immobilize lipases from Y. lipolytica KKP 379 via physical adsorption. The stability of biocatalysts (free and immobilized) was evaluated by measuring the enzyme activity before and after treatment with the method based on the hydrolysis of $p$-nitrophenyl laurate. Two fractions of enzymes were immobilized: cell-bound (yeast biomass) and extracellular (supernatant). The yield of immobilization and catalytic properties of immobilized lipases were investigated. Satisfactory results for lipolytic activity and biocatalyst stability were obtained for cell-bound enzymes immobilized in alginate $(0.38$ $\mathrm{U} \mathrm{g}^{-1}$ d.m.) and crosslinked gelatin $\left(0.18 \mathrm{U} \mathrm{g}^{-1}\right.$ d.m.). Immobilization of the supernatant was successful only on the alginate $\left(0.026 \mathrm{U} \mathrm{g}^{-1}\right.$ d.m.). After lyophilization, no significant difference was noticed between treated and untreated biocatalysts. Lyophilized catalysts were successfully immobilized in all three matrices, but the process reduced their lipolytic activity probably due to an insufficient amount of water in the reaction solution.
\end{abstract}

Key words:

lipase, immobilization, Yarrowia lipolytica, alginate, gelatin, polyvinyl alcohol

\section{Introduction}

Biocatalysts (enzymes and whole cells) are finding increasing applications because of the growing demand for biotransformations in the fine chemicals industry. These biocatalysts, which have high chemo- and stereospecificity, are particularly used in the pharmaceutical, agrochemical, and health care products industries ${ }^{1}$. Historically, enzymes have been used extensively in aqueous media, however, biotransformations in industrial synthesis often involve organic molecules insoluble in water. Over the past 25 years, studies have shown that enzymes can work in organic solvents, and recent advances in protein engineering and directed evolution aided in the development of enzymes that show improved activity in non-aqueous solutions $\mathrm{s}^{2,3}$. Lipases and esterases have received increasing importance in recent years because, for example ${ }^{4,5}$, the organic solvent tolerant cells allow the production of biodiesel. Free lipases are also used in many other two-phase system biotransformations for production of optically active alcohols, acids, esters, and lactones $^{2}$. A classic example is the use of lipase for

"Corresponding author: agata_fabiszewska@sggw.pl the commercial production of $(S, R)-2,3,-p$-methoxyphenylglycyclic acid, an intermediate for diltiazem ${ }^{6}$, a calcium channel blocker used in the treatment of hypertension, angina pectoris, and some types of arrhythmia.

However, the use of enzymes has been limited because of their unstable nature. Industrial applications of biotransformations have become possible mainly due to the development of the immobilization techniques on solid matrices. The immobilization often protects enzymes from environmental stresses such as $\mathrm{pH}$, temperature, salts, solvents, inhibitors, and toxins. Immobilization of cells containing specific enzymes has further advantages, such as elimination of long and expensive procedures for enzyme separation and purification. It is important to expand the application of enzymes by enabling easy separation and purification of products from reaction mixtures and efficient recovery of catalyst ${ }^{7}$.

Microbial cells have been immobilized in several natural polymers like polysaccharides, e.g., alginates and proteins, e.g., collagen or gelatine. The main groups of synthetic polymers used for immobilization are acrylic polymers, vinyl polymers, amide polymers, polyurethanes, and conductive polymers. Mineral matrices have been also used, and 
these include ceramics or glass beads, alumina and sol-gel silica films ${ }^{8}$.

One of the most frequently used enzyme tools in biocatalysis are lipases. Lipases (triacylglycerol ester hydrolases, EC 3.1.1.3) have many industrial applications. They catalyse the hydrolysis of triacylglycerol into glycerol and fatty acids ${ }^{9}$ as well as esters synthesis in organic solvents ${ }^{10}$. Commercially useful lipases are commonly obtained from microorganisms that produce a wide variety of enzymes. Microbial lipases find many applications including organic synthesis and bioconvertions in the food and detergent industries, paper and oleochemical industries, cosmetics, medicine, and waste treatment $^{11,12,13}$. The majority of commercially significant lipases are produced by Candida rugosa, $C$. antarctica, Aspergillus niger, Rhizomucor miehei and Rhizopus arrhizus ${ }^{14,15}$. Lipases are produced intracellularly or extracellularly, although there is a wide range of cell wall - bound enzymes ${ }^{16,17,18}$. Free lipases are not favoured in industrial applications because it is difficult to recover the molecules for their reuse, and they have low stability. These drawbacks could be overcome by using cell-bound enzymes or by immobilization of enzymes on appropriate supports.

Yarrowia lipolytica is one of the most extensively studied "non-conventional" yeasts and due to its high lipolytic activity is often used for biotransformation $^{18}$, e.g., synthesis of flavor compounds ${ }^{19}$. Lipases from Y. lipolytica are isolated intracellularly (cell-bound lipases) and extracellularly, so the culture supernatant and the yeast biomass can be both used as catalysts. Because most papers on the catalytic properties of lipases focus on extracellular lipases, we decided to examine the lipolytic activity of cell-bound lipases of Y. lipolytica as well. For this purpose, yeast biomass, which is the source of cell-bound lipases, was used as a catalyst. The activity of yeast biomass was compared with lipolytic properties of extracellular enzymes present in the supernatant, both in free and immobilized form. Immobilization was carried out on natural polymer bases: calcium alginate and cross-linked gelatin, and on a synthetic base of polyvinyl alcohol. The products of immobilization were applied as catalysts in the hydrolysis of lipophilic ester ( $p$-nitrophenyl laurate).

\section{Materials and methods}

\section{Materials}

All medium ingredients were purchased from BTL (Łódź, Poland). All ingredients for immobilization were purchased from POCH (Poland). Sodium alginate Bio-Reagent was purchased from Sig- ma Aldrich (Poznań, Poland). $p$-Nitrophenyl laurate was synthesized in our laboratory ${ }^{20}$.

\section{Microorganism}

Y. lipolytica KKP 379 was purchased from the Collection of Industrial Microorganisms at Institute of Agricultural and Food Biotechnology in Warsaw. Yeast biomass was characterized by cell dry mass measured using the thermogravimetric method at $105{ }^{\circ} \mathrm{C}$ and by the number of cells measured using plate method on YPG agar medium $(2 \%$ glucose, $1 \%$ yeast extract, $2 \%$ peptone, $2 \%$ agar, $\mathrm{pH} 5.0$ ) at $28^{\circ} \mathrm{C}$ for $72 \mathrm{~h}$.

\section{Culture media and yeast cultivation}

YPGO medium (2\% glucose, $1 \%$ yeast extract, $2 \%$ peptone, $2 \%$ olive oil $\mathrm{pH} 5.0$ ) was used for yeast cultivation. The medium was prepared with distilled water. The yeast was cultivated at $28^{\circ} \mathrm{C}, 400 \mathrm{rpm}$ in bioreactor BioFlo 3000 (New Brunswick Scientific, Germany). Aeration was at $0.2 \mathrm{vvm}$, the initial $\mathrm{pH}$ was 5.0, and the inoculum was $0.025 \%$. Inoculum was prepared as described by Fabiszewska et al. ${ }^{21}$ Optical density (OD) was measured at $600 \mathrm{~nm}$ by the spectrophotometric method.

\section{Measurement of lipase activity}

The measurements of enzymatic activity were conducted using a modified spectrophotometric method described previously ${ }^{22,23}$, which is based on hydrolysis of $p$-nitrophenyl laurate. Reactions were carried out in Erlenmayer flasks $(100 \mathrm{~mL})$ for 30 minutes. $0.3 \mathrm{mmol}$ of substrate suspended in $2 \mathrm{~mL}$ of $n$-heptane was added whilst stirring vigorously to $1 \mathrm{~g}$ of yeast biomass suspended in $15 \mathrm{~mL}$ of distilled water or to a $15 \mathrm{~mL}$ of supernatant. Activity of the biomass of Y. lipolytica was measured using the standard curve and evaluated with standards of $p$-nitrophenol in concentration from $4.4 \cdot 10^{-3} \mathrm{M} \mathrm{L}^{-1}$ to $3.7 \cdot 10^{-4} \mathrm{M} \mathrm{L}^{-1}$. One unit of enzyme activity was defined as the enzyme quantity that liberated 1 $\mu \mathrm{mol}$ of $p$-nitrophenol per minute under the assay conditions at $37^{\circ} \mathrm{C}$.

\section{Measurement of water activity}

The water activities of biomass and supernatant were checked at $18 \pm 1{ }^{\circ} \mathrm{C}$ using the instrument HygroLab3. This instrument is sensitive to the change in equilibrium relative humidity (ERH) around the sample, not directly to moisture content.

\section{Lyophilization procedure}

The cells and supernatant were frozen for 1 hour at $-42{ }^{\circ} \mathrm{C}$, and lyophilized for $24 \mathrm{~h}$ using Christ 
Gamma 1-16 LSC lyophilizer, shelves $10{ }^{\circ} \mathrm{C}$, at a pressure $63 \mathrm{~Pa}$. Safety pressure was $103 \mathrm{~Pa}$, protecting biological material from temperatures above $-20{ }^{\circ} \mathrm{C}$. The lyophilized yeast biomass and supernatant were stored in vacuum desiccators.

\section{Immobilization procedure}

Calcium alginate gel beads were prepared by dropping a mixture containing $15 \mathrm{~mL}$ of $4 \%(\mathrm{w} / \mathrm{v})$ sodium alginate and $1 \mathrm{~g}$ of wet yeast biomass (or $15 \mathrm{~mL}$ of supernatant) into $100 \mathrm{~mL}$ of $2 \% \mathrm{CaCl}_{2}$ whilst stirring continuously. The beads were left to harden for $24 \mathrm{~h}$ in the same $\mathrm{CaCl}_{2}$ solution before being washed with distilled water and stored at $4{ }^{\circ} \mathrm{C}$.

The gelatin matrix was prepared by suspending $1.0 \mathrm{~g}$ cells (or $15 \mathrm{~mL}$ supernatant) in $15 \mathrm{~mL}$ aqueous solution of $20 \% \mathrm{w} / \mathrm{v}$ gelatin and $2 \% \mathrm{w} / \mathrm{v}$ sodium alginate at $36{ }^{\circ} \mathrm{C}$. It was then mixed well and dropped into stirred cold $0.7 \mathrm{M}$ calcium chloride solution. The formed composite beads were left to stand in the same solution for $1.5 \mathrm{~h}$, and then washed with $0.05 \mathrm{M}$ phosphate buffer $\mathrm{pH}$ 7.8. The alginate in the composite was leached until the composite was clear. The porous beads, containing yeast cells, cross-linked with $2 \% \mathrm{v} / \mathrm{v}$ glutaraldehyde, were prepared in phosphate buffer for $2 \mathrm{~h}$ at $4{ }^{\circ} \mathrm{C}$. The cross-linked porous beads were washed several times with cold distilled water.

The PVA matrix was prepared by suspending $1.0 \mathrm{~g}$ cells in $15 \mathrm{~mL}$ aqueous solution of $10 \% \mathrm{w} / \mathrm{v}$ PVA (degree of polymerization $1800 \pm 100$ ) and $0.8 \% \mathrm{w} / \mathrm{v}$ sodium alginate at $36{ }^{\circ} \mathrm{C}$. They were then mixed well and dropped into stirred, saturated boric acid solution. The formed composite beads were stirred in the same solution for $4 \mathrm{~h}$. The beads were washed several times with cold distilled water.

In the case of lyophilized material $0.3 \mathrm{~g}$ lyophilized biomass or $0.3 \mathrm{~g}$ lyophilized supernatant was dissolved in $0.5 \mathrm{~mL}$ distilled water and immobilized, according to the above procedures, in $12 \mathrm{~mL}$ matrices.

\section{Statistical analysis}

Statistical analyses of the results were performed in STATISTICA 10.0 (Statsoft, Poland). P-values with $p \leq 0.05$ were considered statistically significant. The Shapiro-Wilk test was used to check if the populations were normally distributed, while Levene's test and the Brown-Forsythe test were used to assess the equality of variances for a variable calculated for groups. The significance test was chosen on the basis of the following criteria: the number of peer groups, the normality of the variables distribution and homogeneity of variance. With two comparative trials, t-test was used for variables with normal distribution and homoge- neous variance or Welch's test for normally distributed variables and heterogeneous variance. For the analysis of more than two comparison groups, $F$-test was performed for variables with uniform variance or Kruskal-Wallis nonparametric test for variables with heterogeneous variance. The ANOVA analysis and post-hoc Tukey test were also used.

\section{Results and discussion}

\section{Lipolytic activity of yeast cells and supernatant during batch culture}

It is known that lipolytic activity of Y. lipolyti$c a$ is influenced by many factors, including: the type and concentration of the carbon source in the medium, the $\mathrm{pH}$ value of the culture, the oxygen partial pressure, the temperature of the culture and the amount of inoculum ${ }^{24,25}$. Furthermore, cell activity is closely associated with the growth phase of microorganism. This is obviously related to the changing conditions during the period of the culture process $^{26,27,28}$.

For determination of the effects of immobilization on the activity of the yeast cells, the culture conditions were selected in order to ensure that the highest amount of biomass with the best lipolytic properties could be obtained. The impact of culture conditions on lipolytic activity of $Y$. lipolytica KKP 379 was previously investigated in shaken cultures ${ }^{16}$. In this study, the results described by Fabiszewska et al. ${ }^{21}$ were repeated in a batch culture to evaluate lipase production efficiency at bioreactor scale. The biomass yield and $\mathrm{OD}_{600}$ (optical density at $600 \mathrm{~nm}$ ), as well as changes in $\mathrm{pH}$ level and oxygen consumption were determined during $70 \mathrm{~h}$ culture (Fig. 1 and 2).

The biomass yield increased during 48 hours, at which the stationary phase began and an inhibition of yeast cell growth occurred (Fig. 1). This assumption can be confirmed through the analysis of changes in oxygen consumption, $\mathrm{pH}$ and $\mathrm{OD}_{600}$ (Fig. 2). After 24 hours of culture, an increase in the $\mathrm{pH}$ value was observed because of an accumulation of yeast metabolites in the medium. Nevertheless, intense exponential growth of biomass continued for up to 45 hours. After this time, the oxygen consumption decreased and $\mathrm{pH}$ ceased to grow, but remained at a high level (approximately 8) (Fig. 2). The described changes indicated that the cells were in the stationary growth phase and their number was estimated at $8.42 \log \mathrm{CFU} \mathrm{mL} \mathrm{mL}^{-1}$.

The selection of optimum culture conditions was based on the analysis of extracellular lipase activity and activity of yeast biomass (cell-bound lipases), obtained during cultivation (Fig. 3). The cel- 


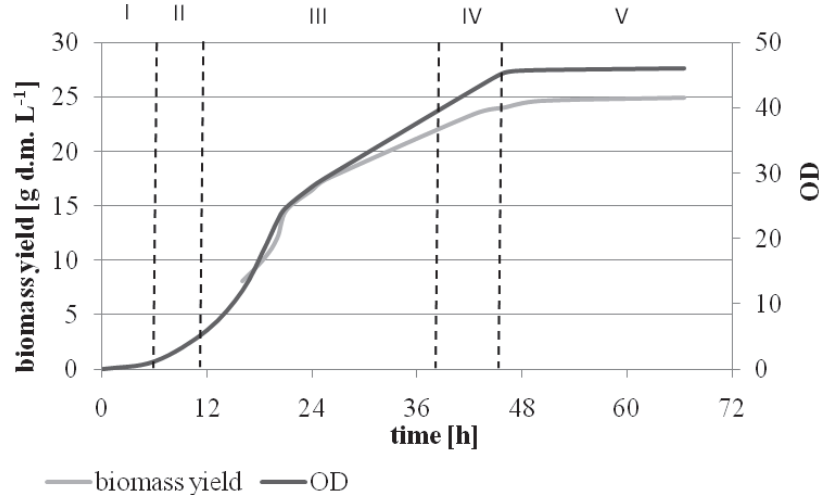

Fig. 1 - Changes in biomass yield and optical density during the batch culture of Y. lipolytica KKP 379. Roman letters mark growth phase: I-adaptive phase (lag phase), II - acceleration phase, III - exponential phase (log phase), IV - phase of declining relative growth, $V$ - stationary phase.

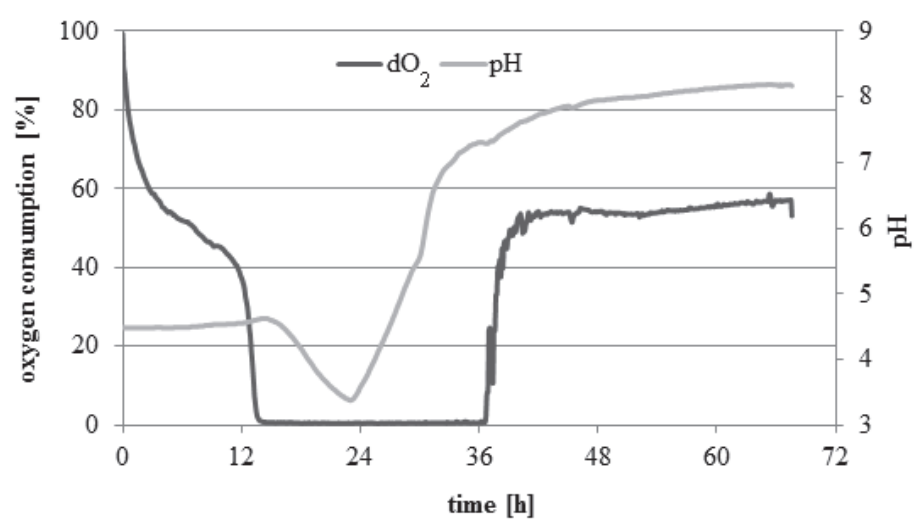

Fig. 2 - Changes in $p H$ and oxygen consumption during a batch culture Y. lipolytica KKP 379

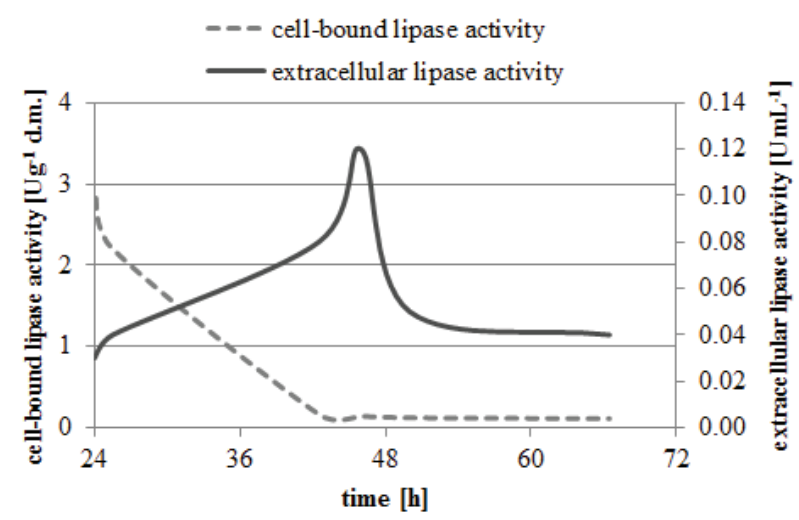

Fig. 3 - Activity of Y. lipolytica cell-bound and extracellular lipases during batch culture

lular activity ceased systematically during the logarithmic phase and was established at a relatively low level in the stationary phase. On the contrary, systematic increase in extracellular lipolytic activity (Fig. 3), lasting up to 46 hours of culture, was noticed. After this time, a decline in extracellular activity was observed. This was probably due to the effect of extracellular lipases digestion related with the activity of alkaline proteases. At the same time, low oxygen consumption (Fig. 2) testified to the fact that the synthesis of the new enzyme was inhibited.

Taking these relationships into account, the biomass and the supernatant, after $40 \mathrm{~h}$ culture, were used for further immobilization and lyophilization. The activity of extracellular lipase was near optimum after this time. In the case of biomass, it was the choice between the lipolytic activity and the amount of yeast cells sufficient for immobilization. The results were compared with material from $70 \mathrm{~h}$ culture (stationary phase), in which both the cell-bound and extracellular activity were low. It allowed comparing the effects of lipase processing on the material derived from the various phases of yeast growth, i.e. the exponential phase and the stationary phase.

\section{Effect of immobilization on activity of cell-bound and extracellular lipases}

Three kinds of matrices (calcium alginate, gelatin, and PVA) were employed as supports to immobilize lipases from Y. lipolytica KKP 379 via physical adsorption. The stability of lipases (free and immobilized) was evaluated by measuring the enzyme activity before and after treatment. The yield of immobilization and catalytic properties of immobilized lipases were investigated.

Before the immobilization, the cell-bound lipase activity of yeast cells from $40 \mathrm{~h}$ culture was slightly higher $\left(0.16 \mathrm{U} \mathrm{g} \mathrm{g}^{-1} \mathrm{~d} . \mathrm{m}\right.$.) than the activity of cells from $70 \mathrm{~h}$ culture $\left(0.11 \mathrm{U} \mathrm{g}^{-1}\right.$ d.m.) (Fig. 4). The highest lipase activity of $0.38 \mathrm{U} \mathrm{g} \mathrm{g}^{-1} \mathrm{~d}$.m. for 40 $\mathrm{h}$ culture, and $0.32 \mathrm{U} \mathrm{g} \mathrm{g}^{-1} \mathrm{~d} . \mathrm{m}$. for $70 \mathrm{~h}$ culture was observed after immobilization on calcium alginate, followed by $0.18 \mathrm{U} \mathrm{g} \mathrm{g}^{-1}$ d.m. and $0.15 \mathrm{U} \mathrm{g}^{-1}$ d.m., respectively, on cross-linked gelatin, and the lowest lipase activity was $0.09 \mathrm{U} \mathrm{g}^{-1}$ d.m. and $0.07 \mathrm{U} \mathrm{g}^{-1}$ d.m. on PVA (Fig. 4). Calcium alginate was more efficient as a support for Y. lipolytica KKP 379 cellbound lipase compared to other supports in the experiment. Lipolytic activity of biocatalyst on the other supports (gelatin and PVA) were not statistically significant according to activity of raw yeast biomass.

The supernatant derived from the $40 \mathrm{~h}$ culture showed activity at a level of $0.08 \mathrm{U} \mathrm{mL}^{-1}$ while supernatant from the $70 \mathrm{~h}$ culture showed activity at a level of $0.013 \mathrm{U} \mathrm{mL}^{-1}$ (data not shown in figures). The immobilization of the supernatant was successful only on the alginate. The lipolytic activity of immobilized supernatant from $40 \mathrm{~h}$ was $0.026 \mathrm{U} \mathrm{g}^{-1}$ d.m. and from $70 \mathrm{~h}$ culture was $0.006 \mathrm{U} \mathrm{g}^{-1}$ d.m. The immobilization on the gelatin and PVA failed, the matrices decomposed during the reaction. The reason for this, in the case of gelatin, may be its 


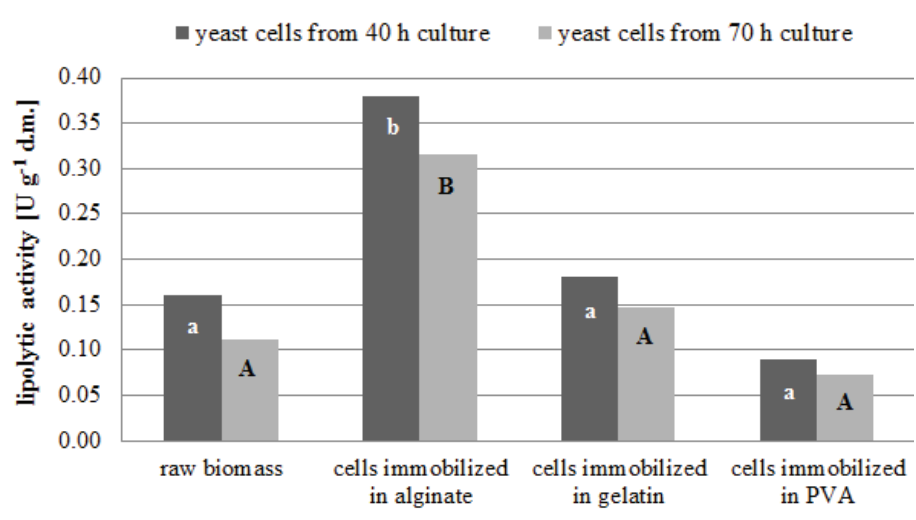

Fig. 4 - Cell-bound lipase activities of raw and immobilized yeast cells. Homogeneous groups designated on the basis of Kruskal-Wallis test were identified by letters. Means were separated into statistically different groups ( $a, b$ or $A, B)$.

hydrolysis under the influence of proteolytic enzymes, which were secreted outside the cells and found in the supernatant. This may be caused by easy transition of gelatin from gel to sol, under the influence of water (swelling phenomenon). Also, in the case of PVA, decomposition occurred under the influence of water contained in the supernatant. This is due to the high hydrophilicity of the polymer. Changes in catalyst activity taking place under the influence of the immobilization process were also illustrated by the results of immobilization yield (Table 1) defined as the ratio of the activity of immobilized enzyme to the activity of the free enzyme used ${ }^{29}$.

The results revealed that the decrease in activity was observed for the alginate - immobilized supernatant from $40 \mathrm{~h}$ and for gelatin-immobilized biomass (Fig. 4). However, in the case of alginate and gelatin-immobilized biomass immobilization, yield is higher than $100 \%$, which indicates an increase in lipase activity (Table 1). The differences resulted probably from the type of applied matrix and its quantity. The amount of lipase immobilized on a carrier was limited because the porous sites at the carriers were saturated. If the support amount was too high, then the lipase molecules seemed to maximize the contact with the surface of support, which may result in a change in lipase conformation and consequently, in reduced activities. However, if a support amount was too low, multilayer adsorption might have occurred and effectively inhibited access to the enzyme active sites ${ }^{30}$.

Table 1 -Immobilization yield of Y. lipolytica KKP 379 biomass and supernatant from $40 \mathrm{~h}$ culture

\begin{tabular}{l|c|c|c}
\hline Immobilization material & $\begin{array}{c}\text { Calcium } \\
\text { alginate } \\
\text { biomass/ } \\
\text { supernatant }\end{array}$ & $\begin{array}{c}\text { Gelatin } \\
\text { biomass }\end{array}$ & $\begin{array}{c}\text { PVA } \\
\text { biomass }\end{array}$ \\
\hline Immobilization yield [\%] & $230 / 32$ & 110 & 55 \\
\hline
\end{tabular}

\section{Effect of lyophilization on lipolytic activity of immobilized biocatalyst}

Lipases are mainly involved in biotechnological production of esters based on the esterification reactions, transesterification, alcoholysis or acidolysis $^{31,32,33,34}$ which can be carried out in non-aqueous organic solvents. Conducting the reaction in organic solvents, with the participation of whole-cell catalysts entails cell dehydration, which can be achieved through lyophilization. Moreover, storing of supernatant absorbs costs and is troublesome because of the mean size of the stored material. Storage in the lyophilized form is easier and more practical, if this way of processing does not affect the activity of the biocatalyst.

Some eukaryotic cells, yeast in particular, are known to contain water in different forms - free, bound, and isolated mobile water (IMW). In the process of lyophilization, when cells lose more than $80-85 \%$ of their water, they pass to a state of anabiosis, which increases cell survival under harsh conditions. Lyophilized yeast cells still contain a certain amount of water, which is bond in various cellular structures - freeze-drying does not lead to disintegration of cellular structures, so all cell organelles are sufficiently separated to function normally ${ }^{35}$. This amount of water is sufficient to provide catalytic activity of lipases, which act at the interface. The effectiveness of freeze-drying is expressed by the water activity $\left(a_{\mathrm{w}}\right)$ in the formulation. The water activity in the biomass and the supernatant was 0.132 and 0.140 , respectively, after lyophilization.

The hydrolytic activity of the lyophilized material (from $40 \mathrm{~h}$ batch culture of $Y$. lipolytica yeast) was compared with the activity of the equivalent amount of non-lyophilized catalysts (Table 2). Therefore, the lyophilized forms were prepared and immobilized. Activity of the free supernatant was translated from $\mathrm{U} \mathrm{mL}^{-1}$ on $\mathrm{U} \mathrm{g}^{-1}$ d.m., taking into account the percentage of dry matter equal to $2.7 \%$, that is why its value exceeds $2 \mathrm{U} \mathrm{g}^{-1} \mathrm{~d} . \mathrm{m}$. In the case of the yeast biomass, we obtained comparable lipolytic activity for lyophilized and non-lyophilized cells at the level of $0.16 \mathrm{U} \mathrm{g} \mathrm{g}^{-1}$ d.m. Similarly, the

Table 2 -Effect of lyophilization on Y. lipolytica lipase activity synthesized during $40 \mathrm{~h}$ batch culture. Activity of the free supernatant translated from $U m L^{-1}$ on $U g^{-1}$ d.m. taking into account the percentage of dry matter equal to $2.7 \%$.

\begin{tabular}{l|l|c}
\hline & Yeast biomass & Supernatant \\
\cline { 2 - 3 } & \multicolumn{2}{|c}{ Lipolytic activity $\left[\mathrm{U} \mathrm{g}^{-1} \mathrm{~d} . \mathrm{m}.\right]$} \\
\hline Before lyophilization & $0.16 \pm 0.009$ & $2.16 \pm 0.025$ \\
After lyophilization & $0.16 \pm 0.015$ & $2.02 \pm 0.015$ \\
\hline
\end{tabular}




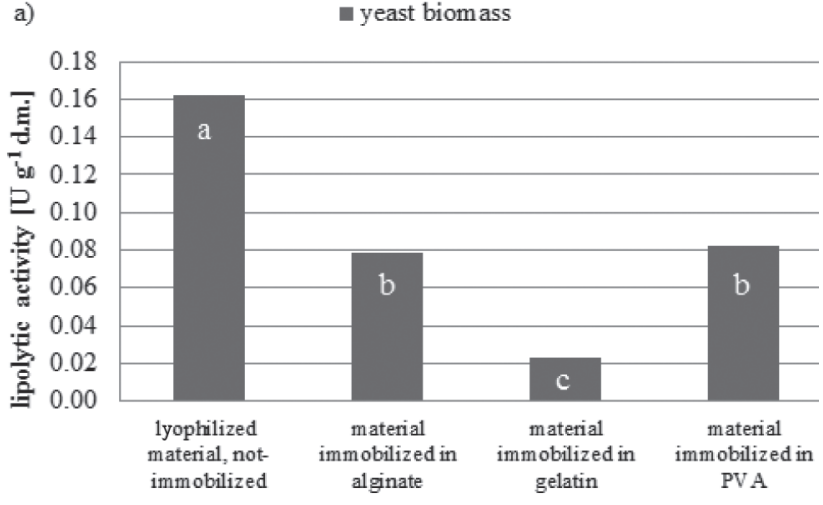

b)

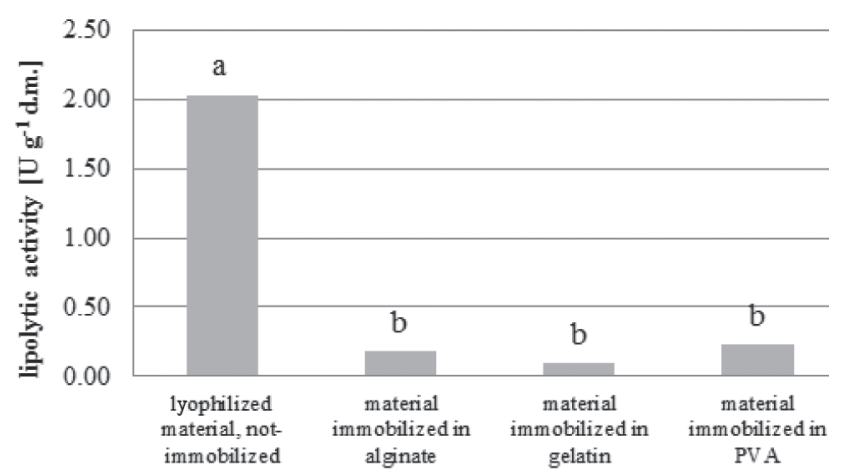

Fig. 5 - Effect of immobilization on the lipolytic activity of freeze-dried yeast cell biomass Y. lipolytica KKP 379 (a) and lyophilized supernatant (b) from $40 \mathrm{~h}$ culture. Homogeneous groups designated on the basis of Welch's test (a) and ANOVA test (b) test were identified by letters. Means were separated into statistically different groups (a or b). Activity of the free supernatant translated from $U \mathrm{~mL}^{-1}$ on $U \mathrm{~g}^{-1}$ d.m. taking into account the percentage of dry matter equal to $2.7 \%$.

lyophilized supernatant showed comparable lipolytic activity than non-lyophilized material (Table 2).

Lyophilization of the supernatant seems to be more advantageous than using a freeze-dried yeast biomass (with respect to $1 \mathrm{~g}$ of biocatalyst) due to the low biomass yield in comparison to the amount of biocatalyst and its activity. The activity of extracellular lipases was the highest at $40 \mathrm{~h}$ of culture (Fig. 3), while the activity of the biomass was the highest at $24 \mathrm{~h}$ (at the beginning of log phase) and then decreased (Fig. 3). In our experiment, the biomass and the supernatant were used from $40 \mathrm{~h}$ of culture.

The lyophilized yeast biomass was immobilized on the aforementioned matrices and assayed its activity in the hydrolysis reaction (Fig. 5). Freeze-drying of yeast cells, prior to immobilization, decreases the activity of the immobilized enzymes and the lowest activity of cell-bound lipases was observed for gelatin matrices (Fig. 5a). This situation was probably due to an insufficient amount of water in the reaction medium.
Supernatant was also subjected to lyophilization and then immobilized in the same matrices (Fig. 5b). The lyophilized supernatant was successfully immobilized on all three polymers. The reason for this could be a reduction in the amount of water in the reaction medium $(15 \mathrm{~mL}$ in the case of crude supernatant to $0.5 \mathrm{~mL}$ in the case of lyophilized). In addition, lyophilization process may stabilize proteolytic enzymes, thus limiting their adverse effect on the gelatin ${ }^{36}$. It should be noted that the catalytic activity of the immobilized supernatant dropped due to lyophilization but no differences were seen, according to matrices used for biocatalyst immobilization (Fig. 5b).

\section{Analysis of the repeated use capability of immobilized biocatalysts}

It is well known that immobilization process facilitates reactions (including the separation of the reactants from the catalyst) and allows the recycling of the catalyst (continuous process) ${ }^{37}$. Therefore, in order to evaluate the reusability of the biocatalyst, hydrolysis reactions were carried out with already used catalysts. The results of the experiment are given in Fig. 6.

The immobilization of microbial cells by entrapment in gels, such as calcium alginate and gelatin, is a well-known technique. However, some authors claim that the entrapment of enzymes in these gels was not very efficient, because such biocatalysts leak out over time due to the matrix having large pores ${ }^{38,39}$. Our results reaffirm this thesis. The activity of the immobilized biomass in both alginate and gelatin in the second reaction cycle significantly decreased. The catalyst entrapped in the matrix of PVA was not able to be used for a second time because during the first reaction, the beads mass increased due to adsorption of large quantities of water. As a result of this process, the beads lost their original hardness and disintegrated or devaluated in a homogeneous mass. The decrease in activity of the catalyst in subsequent cycles of the reaction may have been caused by the insufficient mechanical stability of the beads, which was estimated on the basis of their weight loss during the subsequent reaction (Table 3 ). The results show that both the alginate and gelatin beads lost about $20 \%$ of their weight in the first hydrolysis reaction. During the second repetition, the alginate beads were stable and did not decompose, whereas the gelatin beads lost a further $10 \%$ of their weight. The reason for the further weight loss in the gelatin beads may be the activity of proteases in the yeast cell.

The PVA-alginate beads that were fabricated by Anaye-Delgado et al. were characterized as highly elastic ${ }^{40}$ but the measurement of the beads diameter was not taken into account because it 


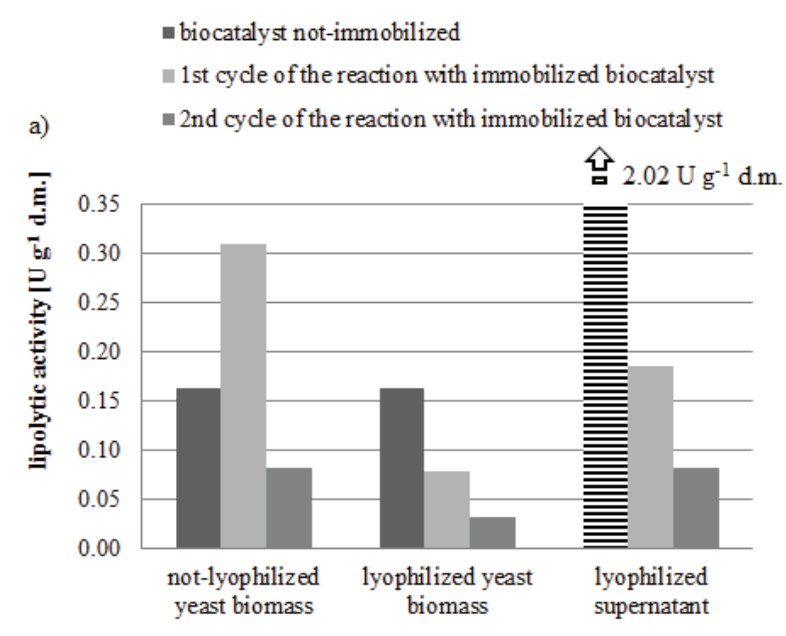

b)

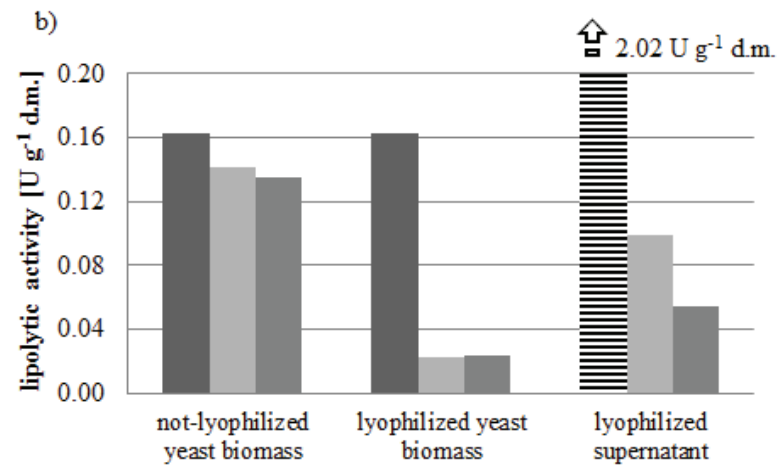

Fig. 6 - Comparison of the activity of immobilized biocatalysts in alginate (a) and gelatin (b), in subsequent reactions. Activity of the free supernatant translated from $U \mathrm{~mL}^{-1}$ on $U \mathrm{~g}^{-1}$ d.m. taking into account the percentage of dry matter equal to $2.7 \%$.

changed after the beads were immersed in water (the beads swell in water). Continuous stirring with constant rpm was conducted for each run of the experiment ${ }^{36}$ and differences were recorded in diameter and weight of their PVA beads before and after stirring. PVA-alginate beads immobilized baker's

Table 3 -The percentage weight loss of alginate beads during two subsequent hydrolysis reactions in relation to the initial weight

\begin{tabular}{l|c|c}
\hline \multirow{2}{*}{ Biocatalyst } & \multicolumn{2}{|c}{ The percentage weight loss [\%] } \\
\cline { 2 - 3 } & $\begin{array}{l}\text { After } 1^{\text {st }} \text { cycle } \\
\text { of the reaction }\end{array}$ & $\begin{array}{l}\text { After } 2^{\text {nd }} \text { cycle } \\
\text { of the reaction }\end{array}$ \\
\hline $\begin{array}{l}\text { Biomass after } 40 \mathrm{~h} \text { culture } \\
\text { Lyophilized biomass after }\end{array}$ & 73.59 & 73.08 \\
$40 \mathrm{~h}$ culture & 83.85 & 81.54 \\
$\begin{array}{l}\text { Lyophilized supernatant } \\
\text { after } 40 \mathrm{~h} \text { culture }\end{array}$ & 86.05 & 85.51 \\
$\begin{array}{l}\text { Biomass after } 70 \mathrm{~h} \text { culture } \\
\text { Supernatant after } 70 \mathrm{~h}\end{array}$ & 82.95 & 78.83 \\
culture
\end{tabular}

yeast invertase ${ }^{24}$ had shown similar results, but in the study, the method was slightly different. Only the weight was recorded after the beads were dried in the desiccator.

\section{Conclusion}

The effect of immobilization on lipolytic activity of supernatant and biomass of Y. lipolytica yeast in raw and lyophilized form was investigated and the following conclusions were made. An interesting observation was made in relation with lipolytic activity of supernatant that the sharp maximum of activity was noticed at about the 48th hour of $Y$. lipolytica cultivation. The effect of immobilization on supernatant and biomass activities was compared. Satisfactory results for lipolytic activity and biocatalyst stability were obtained for yeast biomass (cell-bound enzymes) immobilized on biopolymers - alginate and crosslinked gelatin. The activity of the immobilized biomass on both alginate and gelatin in the second reaction cycle significantly decreased; unfortunately, this restricted their application. Lipolytic activities of supernatant which contained extracellular enzymes as well as biomass (a source of cell-bound lipases) were not affected by lyophilisation. It can be concluded that lyophilization of the supernatant seems to be more advantageous than using a freeze-dried yeast biomass (with respect to $1 \mathrm{~g}$ of biocatalyst) due to the low biomass yield in comparison to the amount of biocatalyst and its activity. Furthermore, lyophilized supernatant can be immobilized on supports, which are sensitive to the high water content in the biological material. The technique offers opportunities for the use of lyophilized biocatalysts in non-aqueous media, thereby increasing its usefulness in chemical synthesis run in organic solvents.

\section{ACKNOWLEDGEMENTS}

This work was supported by the National Science Center, Ministry of Science and Higher Education in Poland under Grant No. N209 107639.

\section{References}

1. Faber, K., Biotransformations in Organic Chemistry. 4th ed., Springer-Verlag, Berlin, Germany, (2011). doi: https://doi.org/10.1007/978-3-642-17393-6

2. Johannes, T., Simurdiak, M. R., Zhao, H., Biocatalysis, Encycl. Chem. Process. (2006) 101.

3. Kumar, A., Dhar, K., Kanwar, S. S., Arora, P. K., Lipase catalysis in organic solvents: advantages and applications, Biological Procedures Online 18 (2) (2016). doi: https://doi.org/10.1186/s12575-016-0033-2 
4. Fukuda, H., Hama, S., Tamalampudi, S., Noda, H., Wholecell biocatalysts for biodiesel fuel production, Trends Biotechnol. 26 (12) (2008) 668. doi: https://doi.org/10.1016/j.tibtech.2008.08.001

5. Carvalho, C. C. R., Whole cell biocatalysts: essential workers from Nature to the industry, Microb. Biotechnol. 10 (2) (2017) 250 . doi: https://doi.org/10.1111/1751-7915.12363

6. Wandrey, C., Liese, A., Kihumbu, D., Industrial biocatalysis: past, present, and future, Organic Process Res. Dev. 4 (4) (2000) 286. doi: https://doi.org/10.1021/op9901011

7. Brodelius, P., Vandamme, E. J., Immobilized cell systems, 405-463, In: Kennedy, J. F. (Ed.), Biotechnology. VCS Verlagsgeselleschaft, Germany, (1987).

8. Stolarzewicz, I., Białecka-Florjańczyk, E., Majewska, E., Krzyczkowska, J., Immobilization of yeast on polymeric supports, Chem. Biochem. Eng. Q. 25 (1) (2011) 135.

9. Fernandez-Lafuente, $R$., Lipase from Thermomyces lanuginosus: Uses and prospects as an industrial biocatalyst, J. Mol. Catal. B Enzymatic 62 (3) (2010) 197. doi: https://doi.org/10.1016/j.molcatb.2009.11.010

10. Haas, M. J., Fox, P. S., Foglia, T. A., Lipase-catalyzed synthesis of partial acylglycerols of acetoacetate, Eur. J. Lipid Sci. Technol. 113 (2) (2011) 168. doi: https://doi.org/10.1002/ejlt.201000477

11. Sharma, R., Chisti, Y., Banerjee, U. Ch., Production, purification, characterization and application of lipases, Biotechnol. Adv. 19 (8) (2001) 627. doi: https://doi.org/10.1016/S0734-9750(01)00086-6

12. Hasan, F., Shah, A. A., Hameed, A., Industrial applications of microbial lipases, Enz. Microb. Technol. 39 (2) (2006) 235. doi: https://doi.org/10.1016/j.enzmictec.2005.10.016

13. Fickers, P., Nicaud, J.-M., Gaillardin, C., Destain, J., Thonart, P., Carbon and nitrogen sources modulate lipase production in the yeast Yarrowia lipolytica, J. Appl. Microbiol. 96 (2004) 742. doi: https://doi.org/10.1111/j.1365-2672.2004.02190.x

14. Kuo, C. H., Liu, Y. C., Chang, C. M. J., Chen, J. H., Chang, C., Shieh, C. J., Optimum conditions for lipase immobilization on chitosan-coated $\mathrm{Fe}_{3} \mathrm{O}_{4}$ nanoparticles, Carbohydr. Polym. 87 (2012) 2538. doi: https://doi.org/10.1016/j.carbpol.2011.11.026

15. Dalmau, E., Montesinos, J. L., Lotti, M., Casas, C., Effect of different carbon sources on lipase production by Candida rugosa, Enzyme Microb. Technol. 26 (2000) 657. doi: https://doi.org/10.1016/S0141-0229(00)00156-3

16. Domínguez, A., Deive, F. J., Sanromán, A., Longo, M. A., Effect of lipids and surfactants on extracellular lipase production by Yarrowia lipolytica, J. Chem. Technol. Biotechnol. 78 (11) (2003) 1166. doi: https://doi.org/10.1002/jctb.922

17. Deive, F. J., Carvalho, E., Pastrana, L., Rúa, M. L., Longo, M. A., Sanroman, M. A., Strategies for improving extracellular lipolytic enzyme production by Thermus thermophilus HB27, Bioresour. Technol. 100 (2009) 3630. doi: https://doi.org/10.1016/j.biortech.2009.02.053

18. Fickers, P., Marty A., Nicaud, J.-M., The lipases from Yarrowia lipolytica, Biotechnol. Adv. 29 (2011) 632. doi: https://doi.org/10.1016/j.biotechadv.2011.04.005

19. Białecka-Florjańczyk, E., Krzyczkowska, J., Stolarzewicz, I., Kapturowska, A., Synthesis of 2-phenylethyl acetate in the presence of Yarrowia lipolytica KKP 379 biomass, J. Mol. Catal. Enzymatic B. 74 (3-4) (2012) 241. doi: https://doi.org/10.1016/j.molcatb.2011.10.010
20. Vogel, A. I., Furniss, B. S., Tatchell, A. R., Hannaford, A. J., Smith, P. W. G. (Eds.), Vogel's Textbook of Practical Organic Chemistry, 5th ed., Prentice Hall, USA, 1996.

21. Fabiszewska, A. U., Stolarzewicz, I., Zamojska, W., Białec$k a-F l o r j a n ́ c z y k, E$., Carbon sources influencing profile of lipases produced by yeast Yarrowia lipolytica, Appl. Biochem. Microbiol. 50 (4) (2014) 404. doi: https://doi.org/10.1134/S000368381404005X

22. Kapturowska, A. U., Stolarzewicz, I., Krzyczkowska, J., Białecka-Florjańczyk, E., Studies on lipolytic activity of sonicated enzymes from Yarrowia lipolytica, Ultrasonics Sonochem. 19 (2012) 186. doi: https://doi.org/10.1016/j.ultsonch.2011.06.015

23. Krzyczkowska, J., Stolarzewicz, I., Białecka-Florjańczyk, $E$., Spektrofotometryczna metoda pomiaru aktywności lipaz $\mathrm{w}$ reakcji hydrolizy laurynianu p-nitrofenylu. Monograph: Wielokierunkowość Badań w Rolnictwie i Leśnictwie 2 (2009) 665 [in Polish].

24. Barth, G., Gaillardin C., Physiology and genetics of the dimorphic fungus Yarrowia lipolytica, FEMS Microbiol. Rev. 19 (4) (1997) 219. doi: https://doi.org/10.1111/j.1574-6976.1997.tb00299.x

25. Lopes, M., Gomes, N., Mota, M., Belo, I., Yarrowia lipolytica growth under increased air pressure: influence on enzyme production, Appl. Biochem. Biotechnol. 159 (1) (2009) 46. doi: https://doi.org/10.1007/s12010-008-8359-0

26. Najjar, A., Robert, S., Guérin, C., Violet-Asther, M., Carrière, F., Quantitative study of lipase secretion, extracellular lipolysis, and lipid storage in yeast Yarrowia lipolytica grown in the presence of olive oil: analogies with lipolysis in humans, Appl. Microbiol. Biotechnol. 89 (6) (2011) 1947. doi: https://doi.org/10.1007/s00253-010-2993-5

27. Yu, M., Qin, S., Tan, T., Purification and characterization of the extracellular lipase lip2 from Yarrowia lipolytica, Process Biochem. 42 (3) (2007) 384. doi: https://doi.org/10.1016/j.procbio.2006.09.019

28. Bordes, F., Tarquis, L., Nicaud, J.-M., Marty, A., Isolation of a thermostable variant of Lip2 lipase from Yarrowia lipolytica by directed evolution and deeper insight into the denaturation mechanisms involved, J. Biotechnol. 156 (2) (2011) 117. doi: https://doi.org/10.1016/j.jbiotec.2011.06.035

29. Idris, A., Azimah, N., Zain, M., Suhaimi, M. S., Immobilization of Baker's yeast invertase in PVA-alginate matrix using innovative immobilization technique, Process Biochem. 43 (2008) 331. doi: https://doi.org/10.1016/j.procbio.2007.12.008

30. Zeng, H. Y., Liao, K. B., Deng, X., Jiang, H., Zhang, F., Characterization of the lipase immobilized on Mg-Al hydrotalcite for biodiesel, Process Biochem. 44 (8) (2009) 791 doi: https://doi.org/10.1016/j.procbio.2009.04.005

31. Akoh, C. C., Yee, L. N., Lipase-catalyzed transesterification of primary terpene alcohols with vinyl esters in organic media, J. Mol. Catal. B: Enzymatic 4 (1998) 149. doi: https://doi.org/10.1016/S1381-1177(97)00029-5

32. Hazarika, S., Goswami, P., Dutta, N. N., Lipase catalysed transesterification of 2-o-benzylglycerol with vinyl acetate: solvent effect, Chem. Eng. J. 94 (2003) 1. doi: https://doi.org/10.1016/S1385-8947(02)00320-0

33. Majumder, A. B., Singh, B., Dutta, D., Sadhukhan, S., Gup$t a, M$. N., Lipase catalyzed synthesis of benzyl acetate in solvent-free medium using vinyl acetate as acyl donor, Bioorg. Med. Chem. Lett. 16 (2006) 4041. doi: https://doi.org/10.1016/j.bmcl.2006.05.006 
34. Yadaw, S. K. N., Adsul, M. G., Bastawde, K. B., Jadav, D. D., Thulasiram, H. V., Gokhale, D. V., Differential induction, purification and characterization of cold lipase from Yarrowia lipolytica NCIM 3639, Bioresour. Technol. 102 (22) (2011) 10663 doi: https://doi.org/10.1016/j.biortech.2011.09.013

35. Shkidchenko, A. N., Nikitin, V. A., Correlation between the cellular content of mobile water and the viability of lyophilized yeast cells, Microbiol. 73 (4) (2004) 431. doi: https://doi.org/10.1023/B:MICI.0000036989.20208.7c

36. Dobrzyński, Ł. J., Zgoda M. M., Biopolimery naturalne jako substancje pomocnicze w technologii dawkowanej postaci leku typu kapsułka. Część I. Miękkie kapsułki żelatynowe jako nowoczesna i efektywna forma produktu leczniczego, Polimery w Medycynie 40 (2) (2010) 11 [in Polish].

37. Kourkoutas, Y., Bekatorou, A., Banat, I. M., Marchant, R., Koutinas, A. A., Immobilization technologies and support materials suitable in alcohol beverages production: a review, Food Microbiol. 21 (2004) 377. doi: https://doi.org/10.1016/j.fm.2003.10.005

38. Won, K., Kim, S., Kim, K.-J., Park, H. W., Moon, S.-J., Optimization of lipase entrapment in Ca-alginate gel beads, Process Biochem. 40 (2005) 2149. doi: https://doi.org/10.1016/j.procbio.2004.08.014

39. Vujčić. Z., Miloradović, Z., Milovanović, A., Božić, N., Cell wall invertase immobilisation within gelatin gel, Food Chem. 126 (2011) 236. doi: https://doi.org/10.1016/j.foodchem.2010.11.010

40. Amaya-Delgado, L., Hidalgo-Lara, M. E., Montes-Horcasitas, M. C., Hydrolysis of sucrose by invertase immobilized on nylon-6 microbeads, Food Chem. 99 (2006) 299. doi: https://doi.org/10.1016/j.foodchem.2005.07.048

41. Khoo, K., Ting Y., Biosorption of gold by immobilized fungal biomass, Biochem. Eng. J. 8 (2001) 51. doi: https://doi.org/10.1016/S1369-703X(00)00134-0 